\title{
Green Politics Theory: Industrialization and Environment
}

\author{
Fitri Juliana Sanjaya ${ }^{1,{ }^{*}}$ Robby Darwis Nasution ${ }^{2}$, Nabillah Audia Putri Utami ${ }^{1}$, \\ Ninda Mirantama ${ }^{1}$ \\ ${ }^{1}$ International Relation Department, Faculty of Social and Political Sciences, Universitas Lampung \\ ${ }^{2}$ Faculty of Social and Political Sciences, University Muhammadiyah Ponorogo \\ ${ }^{*}$ Corresponding author. Email: fitrijuliana@fisip.unila.ac.id
}

\begin{abstract}
This paper discusses shifting focus of security studies to global environmental issues. Environmental issues have become global issues that affect the sustainability of life. Not only developing countries, but also developed countries have experienced environmental and political ecology problems. One of them is linked to industrialization and global warming due to excessive energy consumption and having devastating effects on the environment. Industrialization is the estuary of the root problem, the rate of energy consumption and emissions. Green Political Theory analyzes the role and pace of industrialization in increasing global warming. The state is facing a dilemma because industrialization is the main factor in the economic growth and prosperity of a country, which on the other hand threatens the survival of other living things. This theory wants a country that can invite people to be aware of loving the environment and preserving and not damaging the surrounding environment.
\end{abstract}

Keywords: security, environmental, sustainability, industrialization, green political theory

\section{INTRODUCTION}

Environmental issues in the study of international relations (IR) are not something new [1], especially in the field of environmental security. Since 1960, environmental issues have been included in international agenda, a massive discussion about the importance of environmental conservation are done by a lot of countries, start with the occasion of Stockholm Conference in 1972, and continue with the establish of Rio Conference in 1992 until the signing of The Kyoto Protocol 1997 [1]. The discussion of environmental issues becomes more important because of its potential for causing some conflict.

Those conflicts can be varied, such as the dispute of rare natural resources like the water shortage in the Middle East, as well as conflict between states about the erosion and migration as a result from the environmental damage [2]. Furthermore, environmental problems can also stimulate cooperation between states as a response to the dangers of global warming and environmental degradation [2]. Therefore, climate change has become a global issue that needs to be anticipated by all countries in the world. These problems have driven some effort to increase the awareness of society to do mitigation and adaptation to climate change. Adaptation means adjusting oneself to climate change. Mitigation means preventing greenhouse gasses from increasing.

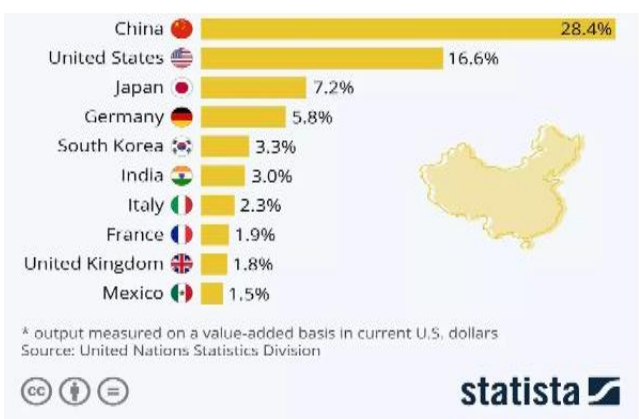

Figure 1. Top Ten Industrial Countries in 2018.[3]

The data above show high income countries as the most industrialized country. The fact is also that some of 
them are the countries with big contributions to the pollution (carbon dioxide and methane) that give significant effect to climate change and cause global warming. Another effect of this climate change is the high air temperature, The change-over of the pattern of a season, and dryness everywhere. Climate change therefore for some opponents was suspected as only a game that was played by the big industries who invented green technology.

It reflects the amount of contention on the negotiation and discussion on reduction of greenhouse gases organized by agencies within the United Nations (UN) or multilateral negotiations. In this case lower middle income countries and low income tend to have an inclination to open up in the global market, and the high income countries tend to have the difficulty in ratifying agreements in energy and environment matters. Take an example to the United States as the world's largest emitter of greenhouse gases, have refused to ratify the Kyoto Protocol. The United States and other high income countries' reluctance to ratify and comply with the Kyoto Protocol is because the commitment to reducing $\mathrm{CO} 2$ emissions means reducing industrialization and consumptions. The rate of industrialization and consumption is very important for the development and progress of a nation. The decline in industrialization and the rate of consumption will affect economic growth and prosperity [4]. Considering these problematic issues several environmentalists put forward various arguments and criticisms related to the phenomenon of environmental damage as a result of the rapid pace of industrialization. These debates in their development resulted in a theoretical approach in understanding global threats as the effects of environmental damage, namely Green Political Theory or often called Green Political Theory.

\section{INDUSTRIALIZATION AND ENVIRONMENTAL}

China as the world's manufacturing superpower began to establish a number of pro-environment policies from 1995 until 2017, and now it has already 14 policies. The first China pro-environment policy is called Circular on Strengthening Environmental Management of Catering, Entertainment and Service Enterprises which aims to make a great environmental management and also protect and improve the environment that is surrounded by this kind of industry. In 2017 China has released another environmental policy called Guidance on Promoting Green Belt and Road with focus on promoting green development, strengthening ecoenvironment protection, and jointly building a green silk road [5].
On one hand, Germany, as the fourth largest industrial country in the world, has established its proenvironment policy ahead of China. Since 1979-2021 Germany already has 39 policies for industries related to energy and the environment. The first German industrial policy that is environmentally friendly and emphasizes the effective use of energy is the Environment Innovation Program. It was a program to support industrial products that are environmentally friendly. In 2021, Germany issued a new policy, called $\mathrm{CO} 2$ Avoidance and Use in Raw Material Industries, which focuses on pursuing the capture of greenhouse gas carbon that cannot be avoided from several types of technology. [6]

The United States on the other hand has more proenvironmental and industrial policies than Germany, namely 41 policies that have existed since 1970 . The first industrial policies of the United States concentrated on energy utilization. For 2022, the United States has made financial policies to reduce carbon emissions and develop technologies to prevent greenhouse gases. [7]

Japan, as the third largest industrialized country in the world, has various types of environmental policies ranging from Environmental Taxation, Environmental Assessment, Environmental Education, Environmental Research/ Technology, Circular and Ecological Economy, Environmental and Economy and Environmental Plan programs as well as some Laws on Environmental Policy. [8]

South Korea policy on Environment varied by some specific themes which is divided into eight topics beginning from Climate Change, Air Pollution, Water Resources, Land \& Waste, Ecosystem, Health and Sustainability and International Relations. In each topic South Korea set some specific goals, first South Korea want to reduce 37 country's emission by 2030 , second is to reduce $35,8 \%$ fine dust before 2022 , and then make sure $99 \%$ Korean have access to tap water supply, next is to be more able in recycling and reborn Korea's wastes as resources, and for Ecosystem South Korea targeting to protect 3392 area for their ecological values, for Health topics Korea approach to make 1125 Country's chemical product should indicate all contained ingredients on their labels, for sustainability and international relation topics Korea adopting all the Sustainable Development Goals Indicator. [9]

India is the highest Industrial Country in the South Asian region, and the Indian states have an industrial policy of maintaining industrial growth, amounting to 10 percent per year. In addition, the State also provides an enabling ecosystem for technology adoption and innovation and promotes sustainable, balanced and inclusive industrial growth [10]. On the other hand, Manufacturing industry is one of the major air polluters in India. Prime Minister Modi launched a campaign promoting "Made in India" products, which garnered wide local and international support [11]. While the 
campaign strategy contributes to India's growth, it is also partly responsible for environmental degradation. Industrialization that relies on fossil power contributes to air pollution. Air contamination is an important problem in the mechanical industry that can affect the health of the entire population [12]. Therefore, India made Policy of environmental protection: Environment Protection Act, 1986; National Conservation Strategy and Policy Statement on Environment and Development, 1992; Policy Statement for the Abatement of Pollution, 1992; National Environment Policy, 2006; Vision Statement on Environment and Health. Law and Regulation of Environmental Protection: water pollution, Air pollution, environment protection, wildlife, forest conservation, biodiversity, national green court, animal welfare [13].

Italy's significant rapid development of renewable energy is ranked in the upper-middle (ranked 18th) in terms of environmental policy. Similar to Italy, France as the main international voice on climate change issues, scored relatively well (ranked 6) in terms of environmental policy. The two countries share a common score in this area which has increased by 1.3 points compared to 2014. While the UK is at the top in the international rankings (rank 6) with a score on this measure having gained 0.7 points relative to 2014 levels. Italian industry is dominated by small and medium-sized enterprises (SMEs), operating mostly in the manufacturing sector with two successive governments pursuing different policies during this period, Italy falling to the bottom (rank 40) to the economic industrial policy in the field of deregulation of the service sector such as banks, insurance companies and so on, to increase competitiveness in these sectors, as well as revamp the industrial sector starting from the main features: production chain [14]. While France has an active role in lobbying at the international level, the government has

Table 1 Top Ten Industrial, Emitters and Environment Policy Performance Global in 2018

\begin{tabular}{|l|c|l|l|}
\hline Country & $\begin{array}{l}\text { Industrialize } \\
\text { Rank }\end{array}$ & $\begin{array}{l}\text { Emitters } \\
\text { Rank }\end{array}$ & $\begin{array}{l}\text { Environment } \\
\text { Policy } \\
\text { Performance }\end{array}$ \\
\hline China & 1 & 1 & n/a \\
\hline United States & 2 & 2 & $-1,2$ \\
\hline Japan & 3 & 5 & $+0,5$ \\
\hline Germany & 4 & 9 & $-0,5$ \\
\hline South Korea & 5 & 11 & $-0,3$ \\
\hline India & 6 & 3 & $\mathrm{n} / \mathrm{a}$ \\
\hline Italy & 7 & 21 & $+1,3$ \\
\hline France & 8 & 19 & $+1,3$ \\
\hline $\begin{array}{l}\text { United } \\
\text { Kingdom }\end{array}$ & 9 & 17 & $+0,7$ \\
\hline Mexico & 10 & 12 & $+0,1$ \\
\hline
\end{tabular}

Source: World Economic Forum, Sustainable Governance Indicator, World Resources Institute [3], [17], [18]. difficulty achieving domestic targets. Despite having a good overall carbon emissions record, France has a strong dependence on an aging nuclear energy sector [15]. In 2016, the British Government also participated in ratifying the Paris Agreement. Post-Brexit occurred; the UK still maintains most of the environmental policy commitments that had been determined at the time of joining the European Union (EU). However, in the business and economic environment, transitioning industry strategies to plans for growth is a priority. [16]

To understand how environmental issues were handled or not, we also need to see how effective a country's policies help to overcome the environmental challenges other than just describing a country's plans and targets. Non-profit think tanks and foundations were very helpful in providing some processed data to answer this question. According to data index by Bertelsmann Stiftung Foundation who measure and examining policy outcomes through Sustainable Governance Indicators (SGI) shows that, in 2020 along OECD and EU countries only 23 of 41 countries who succeeded in improving their policies performance in achieving the sustainable environment relative to 2014, with four countries remain stable and 14 countries even decreased.

If we compare the environmental policies performance of SGI with data on the amount of country's contribution for emission, and the country's industrial rank we can see also that some of the top industrialized and emitter countries have a bad policy performance. The United States is the second largest industrialized country and emitter for the world but also has the worst performance in environmental policy performance. Likewise, Germany failed to improve its policy performance even though its position in the ninth largest rank as a contributor to gas emissions remained the same in the last five years. Different from the US and Germany, Japan has succeeded in improving its policy performance even though it is also the third largest emitter.

\section{GREEN POLITICAL THEORY ANALYZE}

Green political theory sees the growing and increasing industrialization, as well as the Paris Agreement have participated in dealing with the problems of environmental damage that have occurred so far. And because it rejects the basic assumptions of Green Political Theory (GPT) which does not believe that the existing state-systems and world structures can respond to environmental problems effectively. Because this theory actually sees the existing structures as the main cause of the environmental crisis and therefore considers the need for reform and improving these structures.

GPT also agrees on the values of the theory of "the limit of growth" that the economic growth experienced 
by the world in the last few centuries has a direct impact on the current environmental crisis (global warming). The theory argument is "the limit of growth", that economic development (industrialization) and population growth of humans have resulted in interconnected crises. These developments have left the world facing a shortage of resources to feed humans and provide raw materials, and at the same time burden the environment more than its ability to accommodate and process human-made waste.

The world ontologically consists of things that are interconnected with each other and are not a single entity. That all living things and other things are fundamentally alive and exist in an ecological system that is interrelated with one another. Therefore, it is not possible to justify the separation between humans and non-humans. Because there should be no rigid separation between humans and non-humans, then human beings should not and have no right to dominate other creatures or objects other than humans.

According to the GPT, rationality as an important part of modern Western science is actually only an instrument to dominate the non-human environment (also women by men) for the sake of man's own interests. Furthermore, green politics argues, because modern science is always associated with modern institutions such as capitalism, nation-state and modern forms of patriarchy, in responding to environmental problems it is not enough just to centralize power through global and regional institutions.

Technological progress will not solve environmental problems, it will only delay the crisis. We can describe real economic development as a ticking time bomb, piling up problems until they explode into more serious problems and come suddenly and unexpectedly. The problems related to this growth are actually interrelated with each other. Hence the solution must be comprehensive.

Nation-states are too big and too small to deal with this environmental crisis, and new global and regional structures are therefore needed (along with decentralization within states). Build and develop the socalled "lifeboat ethic". The favor for a community that is small in scale, has strong ties to one another, is hierarchical, participatory, egalitarian and conservative in the sense of being more self-sufficient in the use of natural resources. Reject freedom and egoism in the use of the environment (environmental anarchism).

The issue of global environmental issues has led to various debates that seek to explain the seriousness of the problem as well as how to cause and handle it. The debate that seeks to explain the seriousness of environmental problems for mankind is the debate between the "modernists" and the "ecoradicals" [19]. Regarding environmental issues, modernists are of the view that continuous improvement in scientific knowledge as well as in technological competition will produce skills that humans can use to control the environment. In other words, humans will continue to improve their skills and techniques in producing and consuming in an environmentally friendly way. Meanwhile, the ecoradicals view that the earth's ecosystem has only a limited capacity. Therefore, harsh population control and dramatic changes in modern lifestyles towards an environmentally friendly way of life, is an important thing to save the environment.

And after the Kyoto Protocol failed to overcome the global warming caused by industrial pollution, in 2016 Paris Agreement was made as a new dream and momentum of global climate movement. The realization of the Paris Agreement itself [20] on adaptation to the negative impacts of climate change, also a dream toward climate resilience, low-emission development without threatening food production, and preparing funding schemes for low-emissions and climate-resilient development, requires collaborative work and mutually supportive actions between countries. All this effort not only becomes a country's responsibility on a global level, but also needs the contribution of non-state actors such as corporations, remember that corporations also give significant contributions to climate change. CDP report [21] shows that 100 energy corporations were contributing $71 \%$ from all industrial emission. Not only from the energy sector, the top 15 food and beverage companies from the United States produce nearly 630 million metric tons of greenhouse gases annually.

The Paris Agreement exists not only to facilitate the state actor and regional or global institution, and corporation. But also, to overcome and mitigate carbon and emission, strengthen the adaptation effort due to the loss and damage caused by climate change. The Paris Agreement also provides aid for countries who want to develop a sustainable green economy.

\section{CONCLUSION}

Industrialization has two faces, on the one hand it is a major factor in improving the economy of a country. But on the other hand, he has a cruel face as a destroyer of the environment and navigates climate change to global warming. If development and industrialization destroy the environment and threaten the life of the human species, the question is what about the survival of future generations?

Green political theory sees that the growing and increasing industrialization, as well as the Paris Agreement have more or less started to help in dealing with the problems of environmental damage that have occurred so far. The factual dilemma of the Paris Agreement and the basic assumption of this theory is that it does not believe in the state-system, but in its journey 
the existing world structure begins to respond to environmental problems, although its efforts cannot be said to be effective. The structure can be the main cause of the environmental crisis, on the other hand it can be a solution. Where necessary these structures are reformed and improved. "Think globally, act locally", the slogan relates to the argument for the need for decentralization of power; from global level to local level.

\section{REFERENCES}

[1] John Vogler in Brian White, Richard Little, and Michael Smith, 1997, Issues in World Politics, London: MacMillan Press Ltd, page 222

[2] Robert Jackson and Georg Sorensen, 2005, Pengantar Studi Hubungan Internasional, Yogyakarta: Pustaka Pelajar, page 323

[3] World Economic Forum. 2018. These are the top 10 manufacturing countries in the world, https://www.weforum.org/agenda/2020/02/countrie s-manufacturing-trade-exports-economics/, Accessed on 27/8/2021.

[4] Winarno, Budi. 2011. Isu-Isu Global Kontemporer. Yogyakarta: CAPS, page. 145

[5] Ministry of Ecology and Environment The People's Republic of China. 2021, Environmental Policies, http://english.mee.gov.cn/Resources/Policies/polici es/. MEE. Accessed on 20/7/2021.

[6] International Energy Agency. 2021. Policies Database, https://www.iea.org/policies? country $=G$ germany sector $=$ Industry \&page $=2$, IEA. Accessed on $18 / 7 / 2021$

[7] International Energy Agency. 2021. Policies Database, https://www.iea.org/policies? sector=Ind sector = Industry \& country=United\%20States, IEA. Accessed on 19/7/2021

[8] Ministry of Environment. Government of Japan, 2021. Environmental Policy, https://www.env.go.jp/en/policy/index.html, Tokyo: MoE. Accessed on 9/8/2021.

[9] Ministry of Environment. 2021. Climate Change, Air Pollution, Water Resources, Land \& Waste, Ecosystem, Health and Sustainability and International Relations. Sejong: MoE. Accessed on 9/8/2021.

[10] NOVO JURIS LEGAL. 2020. Thought Leadership Salient Features of New Industrial Policy 2020. https://www.novojuris.com/thoughtleadership/salient-features-of-new-industrialpolicy-2020-25.html. Accessed on 3/9/2021.
[11] Aldrich, J.H. et al., 2015. Getting out the vote in the social media era: Are digital tools changing the extent, nature and impact of party contacting in elections? Party Politics, 22(2), pp.165-178.

[12] Project guru. Manufacturing industries as the major source of air pollution in India. https://www.projectguru.in/air-pollution-india/ Accessed on 3/9/2021.

[13] International Center for Environment Audit and Sustainable Development. http://iced.cag.gov.in/?page_id=256, Accessed on $1 / 8 / 2021$.

[14] Francesca Pantaleone. 2016. Competitiveness Enhancement Policy. Francesca Pantaleone. page. 15 .

[15] Sustainable Governance Indicators. 2021. French https://www.sgi-network.org/2020/France.

Accessed on 1/8/2021.

[16] The UK's Industrial Strategy. https://www.gov.uk/government/topicalevents/the-uks-industrial-strategy. Accessed on $1 / 8 / 2021$.

[17] Johannes Friedrich, Mengpin Ge and Andrew Pickens. 2021. This Interactive Chart Shows Changes in the World's Top 10 Emitters. https://www.wri.org/insights/interactive-chartshows-changes-worlds-top-10-emitters. Washington DC: WRI. Accessed on 3/8/2021.

[18] Bertelsmann Stiftung. 2021. Sustainable Governance Indicators: Do environmental policies address sustainability issues? https://www.sginetwork.org/2020/Sustainable_Policies/Environme ntal_Policies. Gütersloh: Bertelsmann Stiftung. Accessed on 3/8/2021.

[19] Robert Jackson and Georg Sorensen, 2005, Pengantar Studi Hubungan Internasional, Yogyakarta: Pustaka Pelajar, page 325

[20] Paris Agreement, United Nations, Retrieved from: https://unfccc.int/sites/default/files/english_paris_a greement.pdf Accessed on 3/8/2021.

[21] Griffin, Paul. (2017). The Carbon Majors Database: CDP Carbon Majors Report 2017. London: CDP 